\title{
Rheme and Theme in Arabic
}

\author{
Tawfeeq Alghazali
}

Director, Islamic University College

\begin{abstract}
This paper is mainly concerned with the notions of theme and rheme as a source for the organization of the clause as a message. It builds on Halliday (1994) who conceives theme as a clause initial element. The framework of Systemic Functional Linguistics focuses on investigating the functions performed by marked Theme. The paper is an attempt to show how the theme is identified in the Arabic clause. The importance of the notion of theme stems from the fact that the flow of information in a sentence from theme to rheme is important to convey the message effectively.
\end{abstract}

Keywords: Focused Information. Unmarked and Marked Theme, Simple and Multiple Themes, The concept of theme and rheme,

\section{Introduction}

Systemic Functional Linguistics (SFL) claims that language is structured to make three main kinds of meanings simultaneously, that is, three met functions (Halliday, 1994: 39): ideational (a function forrelating experience), interpersonal (a function for creating interpersonal relationships), and textual (a function for organizing information). Halliday and Matthiessen (2004: 64) define Theme as "the element which serves as the point of departure of the clause within its context" Marked Theme is a variation of unmarked Theme in specific contexts. Theme is merely limited to the fields of rhetorical use and pragmatic application.

\section{The Concept of Theme and Rheme}

Many linguists have started to investigate the message structure of the clause. Mathesius (1939) is the first who put forward the concepts of theme and rheme. According to him, theme is the part that comes first in a sentence and rheme remains the following part. In general, theme carries the old information while the rheme the new. Danes (1964: 225) defines theme as the element placed in the beginning of the sentence. His main contribution is represented by the concepts of the thematic progression in which he shows how theme becomes the rheme in the following clause and how theme is repeated in consequent clauses (Firbas, 1976:11). Generally, For the Praguean linguists, theme is the carrier of the lowest degree of the communicative dynamism. The communicative dynamism is the element that contributes least to the development of the discourse. Such an element is retrievable from context and carries the given information (Firbas, 1996:66). Theme-rheme classification refers to the organization of the clause as a message. Theme is what is spoken about, whereas rheme is what is said about the theme. Steedman (2000:649) argues that a theme is " what the participants have agreed to talk about while a rheme is the speaker's new contribution on the subject of the theme as in example (1) below:

\section{ZaidunnajiHun ( )ُّذ واجخ)}

Zaid is successful

The example (1) above consists of the theme "Zaidun" and the rheme "najiHun". In other words, "Zaidun" is a person about whom something is said, whereas, "najiHun" is what is said about "Zaid". As mentioned earlier, the theme- rheme classification was studied first by the Praguean linguists. According to Halliday (1985:53), language contains three major functions. These functions are briefly represented in $(\mathrm{A}, \mathrm{B}$, and $\mathrm{C})$ below:

a) The identical function:

This function indicates a strategy to express our experience of the world.

b) The interpersonal function

This function refers to a strategy to establish and maintain social relationship.

c) The textual function

This function refers to a strategy to create "texture" and to make language operationally relevant. As a linguistic unit, the clause can be analyzed according to the ideational, interpersonal, and textual meanings asin example (2) below:

\section{Laylakatabat al-Qaseedatah (( ) لِلعبثَت القصذذة \\ Layla wrote the poem}

In the example (2) above it can be analyzed ideationally, interpersonally, and textually. Ideationally, it is analyzed as actor (i.e. Layla), process (i.e. katabat), and goal (i.e. alQaseedatah). The interpersonal analysis shows the role taken up by the speaker in the speech situation and the attitudes he adopts towards what he is saying. Hence, interpersonally, it is analyzed as subject (i.e. Layla), predicator (i.e. katabat), and object (i.e. al-Qaseedatah). Textually, this clause is analyzed as theme "Layla" and rheme "katabat al-Qaseedatah" and the clause organization is viewed here as a message (Halliday, 1985:28-29)

\section{Simple and Multiple Themes}

A theme can be simple or complex. A simple theme is realized by a single element in the clause. This theme indicates an ideational meaning. Hence, the theme represents a process, a participant in the process, or a circumstance associated with that process. The simple theme is also called the topical theme (Halliday, 1985:54). The ideational theme can be recognized as the first element in the clause that expresses some kind of representational meaning (Martin et al. 1997:24). The following examples clarify this:

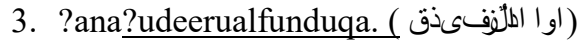

I manage a hotel

ThemeRheme 


\section{International Journal of Science and Research (IJSR) \\ ISSN (Online): 2319-7064}

Index Copernicus Value (2013): 6.14 | Impact Factor (2014): 5.611

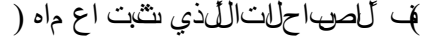

4. fi al-sabaHal-ta:liladayyathalatheta ?a?ma:l

In the next morning I had three jobs

Theme Rheme

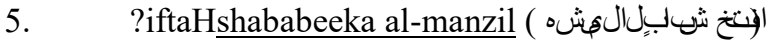

Open windows the house

ThemeRheme

The theme in sentence (3) is an agentive participant; the theme in sentence (4) is a circumstance; and in sentence (5), it is a process. A multiple theme, on the other hand, consists of, in addition to the ideational element, one more elements expressing interpersonal and/or textual meanings. The interpersonal theme precedes the topical theme. Butt et al. (1995: 25) state that the interpersonal theme includes the finite element, the wh-element, the vocative and the adjunct. wh-element signals that the addressee should present an answer, as in example (6):

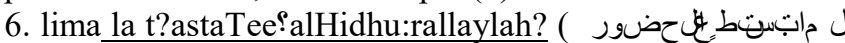

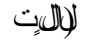

Why not can attend tonight

ThemeRheme

\section{Unmarked and Marked Theme}

It is generally assumed that Theme, in the typically unmarked form, bears the burden of conveyance of Given information and Rheme serves as the conveyer of New information. Marked Theme, as variation of unmarked Theme in certain contexts, is supposed to fulfill the following miscellaneous functions of transmitting information:

\section{Focused Information}

Under certain circumstances, the linguistic elements serving as focused information normally in Rheme, are likely to be moved to the initial position of the clause and actually function as marked Theme. Hence, focused information mapped on to marked Theme is fore grounded, that is, its salience function is fulfilled. Such prominently marked information usually embodies the characteristics of uniqueness and exhaustiveness (Huddleston, 1988: 187 ). As in (7)

7. ALIUN ?ismahu. ( علَّسمٍ )

Ali his name is

\section{Relational Information}

It normally exists itself as an individual tone group to convey new information. That is, such clauses often have double tone groups, one tonic salience falling on the marked Theme, and the other on a subsequent element of the clause ( mostly likely terminal ).

For example:

8.?nnahu SALIM allathikasaraalnafitha. ( أسَالمالذبيمسز 
It was Salim who broke the window

\section{Emphasis on the New Information in Rheme}

In written Arabic, marked Theme seems to have the particular function of arranging clause sequence in order that end-focus falls on the most important part of the information. Therefore, marked Theme is likely to perform the function of highlighting New information in Rheme.

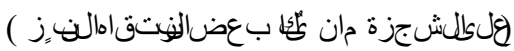

9. ?ala al- shajarati kana hunakaba 9 dh al- burtaqa:l al-kabeer

On the tree were there some the- oranges the- large

On the tree there were some large oranges

\section{Textual Theme}

The textual theme occurs at the first part of theme coming before the interpersonal theme. The textual themes are represented in (10)

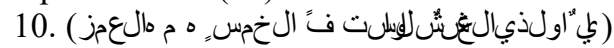

\begin{tabular}{|c|c|c|c|}
\hline . ?ahin, & yawaladi al؟azeez, & ?ana & $\begin{array}{c}\text { lastu fi alxamseen } \\
\text { mina al?umr. }\end{array}$ \\
\hline Oh, & my dear boy, & I & m not fifty years old \\
\hline $\begin{array}{c}\text { Textual } \\
\text { theme }\end{array}$ & $\begin{array}{c}\text { Interpersonal } \\
\text { theme }\end{array}$ & $\begin{array}{c}\text { Ideational } \\
\text { theme }\end{array}$ & Rheme \\
\hline
\end{tabular}

The fact that in the unmarked sequence of these elements in the multiple theme, the textual theme comes first followed by the interpersonal theme which is in turn followed by the ideational theme (Halliday, 1985: 53).

\section{Conclusions}

The following points are concluded from this study:

1) The writer or the speaker decides where to start the sentence and the beginning of each sentence is its theme. The rest of the sentence tells the reader or the listener something about the theme. And the rest of the sentence is called rheme. The theme is the framework of the point of the departure of the message. The rheme is what the addresser wants to convey about the theme.

2) A clause can be analyzed ideationally, interpersonally, and textually.

3) When the three types of theme are present in the clause, the textual theme should come first followed by the interpersonal theme which should in turn be followed by the ideational theme.

4) The operator is the theme in a polar interrogative clause; while the wh-element is the theme in a content interrogative clause.

\section{References}

[1] Butt, D., Fahey, R., Spinks, S. and Yallop, C. (1995).Using Functional Grammar: An Explorer's Guide. Australia, National Centre for English Language Teaching and Research, Macquarie University.

[2] Danes, F., (1964): A three-level approach to Syntax. Travaux Linquistiques de Prague, 


\section{International Journal of Science and Research (IJSR) \\ ISSN (Online): 2319-7064}

Index Copernicus Value (2013): 6.14 | Impact Factor (2014): 5.611

[3] Firbas, J. (1976): A Study in the Functional Sentence Perspective of the English and Slovanic Interrogative sentence. Brno Studies in English

[4] (1996) Exploring Vilem Mathesius' Use of

The Term Theme (part II). Linguistica Pragensia. Halliday, M.A.K. (1985): An Introduction to Functional Grammar. London: Edward Arnold.

[5] _ (1994): An Introduction to Functional Grammar, Second Edition, London: Edward Arnold.

[6] Halliday, M. A. K. \&Matthiessen, C. M.I. M. An Introduction to Functional Grammar (3rdedition). London: Arnold, 2004

[7] Huddleston, R. English Grammar: An Outline. Cambridge: Cambridge University Press, 1988

[8] Martin, J.R., Matthiessen, C.M.I.M., Painter, C., (1997) Working with Functional Grammar, London: Edward Arnold.

[9] Mathesius, V., (1939): On the So-called functional Sentence Perspective. In Solvo a Slovestnost.No5. pp.177-239. 